\title{
ULTIMA SPES: REGSVERNUWING EN REGSIDEALISME 1
}

\author{
D.H. van Zyl \\ Departement Romeinse Reg en Regspluralisme \\ Potchefstroomse Universiteit vir $\mathrm{CHO}$ \\ POTCHEFSTROOM
}

\begin{abstract}
Law reform in South Africa should meet the criterion of legal tdealism, as legal idealism embodics the principle of equal justice for all. With this viewpoint the historical development of the concept justice is traced in this article. Furthermore the importance of Roman law. legal histor: comparative law and legal pluralism in contemporan and future South Africa is discursed. Recen developments, eg. the South African Law Commission's Bill of Rights and the refom of procedural law, are referred to by the author. The conclusion arrived at is that if law reform is based on justice, the highest hopes for a just legal order may be realised.
\end{abstract}

Die hooftitel van hierdie artikel, ultima spes, is, in die dae waarin ons tans leef, betekenisvol. Dit sou as 'laaste hoop' vertaal kon word. maar ek verkies om dit as 'hoogste verwagting' weer te gee, aangesien my boodskap aan u een van optimisme en idealisme is eerder as van pessimisme en wanhoop. Ek het ook gedink dat dit gepas is om 'n Latynse begrip te gebruik in hierdie dae van bevraagtekening van esoteriese vakgebiede soos Klassieke Tale, Romeinse reg, Regsgeskiedenis en selfs Regsvergely. king en Regspluralisme, wat so eie aan ons land is. Die bevraagtekening hang saam met oproepe om regshervorming en regsvernuwing wat deur baie persone, veral politici, as 'n ideaal op sigself beskou word. Dit is 'n oogmerk van hierdie artikel om die begrip regsidealisme in 'n behoorlike perspektief te plaas, waarskynlik met 'n mate van subjektiwiteit wat onder die omstandighede beswaarlik vermy sou kon word. Daarna wil ek kortliks kyk na die regshervorming of regsvernuwing wat reeds in Suid-Afrika plaasgevind het, of besig is om plaas te vind, of slegs nog in die vooruitsig gestel word. $\mathrm{Na}$ aanleiding hiervan sal dit miskien moontlik wees om te bepaal of die regsvernuwing aan die eise van regsidealisme voldoen. Indien wel, sal daar dan ook moontlik aan ons hoogste verwagting, ons ultima spes, voldoen kan word. Alvorens ek egter daarby uitkom, wil ek graag enkele inleidende opmerkings maak.

1 Oorspronklik gelewer as intrecrede met dic aanvaarding van 'n creprofessorraat in dic Departement Romeinse Reg en Regspluralisme aan dic PU vir CHO - 17 Mei 1991. 
Ultima spes: regsvernuwing en regsidealisme

\section{INLEIDING}

Die regsidealisme wat ek voorstaan, hang saam met die hoë verwagtinge wat ek koester vir die reg en regspleging in hierdie veranderde tye, tye wat soms onstuimig en ontstellend mag wees, dog altyd opwindend en stimulerend bly. Ek praat nie as politikus of ekonoom nie - sulke dissiplines val buite die kennis, kundigheid en ervaringsgebied van die meeste regsgeleerdes. Ek praat as 'n liefhebber van die reg, wat die hoogste eerbied daarvoor het en die hoogste verwagtinge van die pleging daarvan koester. Ek praat as 'regsidealis'.

Die hoogste ideaal wat enigeen, en bepaald enige regsgeleerde, ten opsigte van die reg kan hê, is dat reg en geregtigheid in alle opsigte, teenoor almal wat daardeur geraak word, sal geskied. Die reg en geregtigheid wat ek aanhang en waaraan my lewe en dié van my kollegas op die regbank toegewy is, word gekenmerk deur eienskappe wat soos clichés mag klink, maar wat tog essensieel vir die bestaan en handhawing daarvan is. Ek dink hier aan billikheid, redelikheid, goeie trou, goeie sedes en die beskerming van die regte van elke individu wat deel van die gemeenskap vorm, onderhewig aan die belange van die gemeenskap as geheel.

Hierdie regsidealisme kan en moet aanwesig wees gedurende die hele proses van regstoepassing, maar ook in die proses van regsverandering of -wysiging soos wat tans uit alle oorde bepleit word en inderdaad lewendig aan die gang is. In hierdie verband word daar veelal gepraat van regshervorming of regsvernuwing.

Die vraag kan met reg gestel word wat hierdie onderwerp te doen het met klassieke Latyn en Grieks, met moderne tale, met Romeinse reg en regsgeskiedenis, met regsvergelyking en regsfilosofie en, les bes, met regspluralisme? Die antwoord hierop is: dit het álles daarmee te doen. Al hierdie dissiplines, tesame met 'n hele aantal wat ek nie genoem het nie en tesame met maatskaplike, ekonomiese en dergelike oorwegings, is wesenlik vir 'n behoorlike begrip van die agtergrond en infrastruktuur, as ek dit so mag beskryf, van die regsvernuwing wat tans plaasvind en wat in die toekoms beoog word. Ek beklemtoon hierdie agtergrond of infrastruktuur om 'n spesifieke rede. Dit hou verband met 'n gesprek wat ek 'n jaar of twee gelede met 'n vooraanstaande lid van 'n bekende politieke beweging hier te lande gehad het. Albei van ons was aanwesig by 'n konferensie oor die toekoms van Latyn as voorvereiste vir toelating tot die advokatuur.

Sterk menings pro en contra die behoud van Latyn is deur verskeie konferensiegangers uitgespreek. Die persoon met wie ek gepraat het, was 'n fel teenstander van nie alleen 
Latyn nie, maar ook van die tans geldende Suid-Afrikaanse reg met sy Romeinse, Romeins-Hollandse en Engelse wortels. Hierdie reg, het hy gesê, moet in die vernuwingsproses uitgegooi word, aangesien dit nie met die nuwe orde, wat deur sy beweging in die vooruitsig gestel word, te versoen is nie. Ek het hom gevra wat hy in die plek daarvan wou stel. Sy antwoord was: die reg wat vir die meerderheid van die SuidAfrikaanse bevolking aanvaarbaar sal wees, die reg wat eie aan hulle is en deur hulle verstaan word, die reg van Afrika. Hiervan het ek afgelei dat hy inheemse reg en regsinstellings voorstaan as plaasvervanger van die Suid-Afrikaanse gemene reg, wat hy as Westers, en dus vir die meerderheid Suid-Afrikaners as volksvreemd aansien. Ongelukkig moes die konferensie voortgaan, sodat ons die gesprek nie kon voltooi nie. Ek het egter wat hy gesê het, ernstig opgeneem en tot die gevolgtrekking gekom dat sy mening nie eenvoudig as onaanvaarbaar of aweregs verwerp kan word nie. Natuurlik moet daar in 'n regspluralistiese land soos Suid-Afrika volledige erkenning aan inheemse reg en regsinstellings verleen word. Dit sou trouens kortsigtig wees om dit nie te doen nie. Maar beteken dit dat die bestaande reg in sy geheel tot niet gemaak moet word? My antwoord hierop is 'n ondubbelsinnige nee. Die gemene reg van SuidAfrika, en inderdaad van die grootste deel van Suider-Afrika. het oor 'n tydperk van eeue diep ingewortel geraak, en dit sou haas onmoontlik wees om dit eenvoudig tot niet te maak. Gooi jy dit weg, dan verloor jy 'n wesenlike deel, indien nie die wese nie, van die substraat waarop die nuwe Suid-Afrika gebou moet word. Dit sou ook beteken dat die rykdom van 'n menigte ander regstelsels, waarnatoe ons ons sou kon wend vir leiding in die proses van regsvernuwing en ter bereiking van die regsideale waarna ons almal streef, eweneens uitgesluit sou word. Geen regdenkende sou 'n medewerker tot so 'n negatiewe, teenproduktiewe en aftakelende proses kon wees nie.

Ter ontwikkeling van hierdie onderwerp meen ek dat dit gerade sal wees om die een en 'n ander te sê oor die geregtigheidsbegrip in sy vroegste verskyningsvorms, naamlik in die Griekse en Romeinse regsdenke. Dit is dieselfde begrip wat in die latere regsontwikkeling en uiteindelik in ons Suid-Afrikaanse gemene reg 'n tuiste gevind het. Die doel van hierdie oefening is om daarop te wys dat geregtigheid, synde die hoogste ideaal waarna ons mag streef, nie uit die moderne menseregte-idioom ontwikkel het nie, maar inderdaad so oud is as die berge. Dit sal ook onteenseglik die relevansie van regsfilosofie en regsgeskiedenis in die huidige tydvak van vernuwing en hervorming aantoon. Daarna word, steeds regshistories, gekyk na die plek van Romeinse reg en die Suid-Afrikaanse gemene reg, oftewel die 'Romeins-Hollandse' reg, soos dit gewoonlik bekend staan, in die vernuwings- en hervormingsproses. Dit word opgevolg deur ' $n$ kort bespreking van die rol wat regsvergelyking in hierdie proses kan speel. Dit kan veral van nut wees wanneer die regspluralisme wat in Suid-Afrika en in ander dele

Koers 57(1) 1992:3-29 
van Suider-Afrika aanwesig is, van naderby beskou word. Met hierdie agtergrond word enkele fasette van die regsvernuwing hier te lande dan in oënskou geneem. Dit spreek vanself dat, vir die doeleindes van hierdie artikel, daar slegs in die breedste trekke met geselekteerde onderwerpe gehandel kan word en wel ter illustrasie van die raakpunte wat daar tussen regsvernuwing en regsidealisme bestaan of behoort te bestaan.

\section{DIE OORSPRONG VAN GEREGTIGHEID}

Die Griekse epiese digters, Homeros en Hesiodos, wys daarop dat geregtigheid in die Griekse regsdenke 'n mitologiese oorsprong gehad het en verpersoonlik is deur die Griekse gode Themis en Dike. ${ }^{2}$ Daarna het die geregtigheidsbegrip 'n rol gespeel in die onderskeid tussen die begrippe nomos (wet of reg) en logos (rede) wat in die voorSokratiese natuurregsfilosofie voorgekom het. ${ }^{3}$ Hierdie begrippe het in die tydperk van die Sofiste en Sokrates bly voortbestaan, maar 'n duidelike onderskeid is getref tussen reg (nomos) en natuur (physis). ${ }^{4}$ Dit was egter Plato wat die begrip geregtigheid (dikaiosyne) tot een van die primêre of kardinale deugde verhef het, die ander deugde synde wysheid (sophia) of verstandigheid (phronesis), dapperheid (andreia) en matigheid (sophrosyne). Geregtigheid was dus 'n etiese of morele begrip en nie 'n regsbegrip as sodanig nie. ${ }^{5}$

Van groot belang is die beginsel wat Plato van Simonides oorgeneem het en wat lui: dit is regverdig (dikaion esti) om aan elk te gee wat hom toekom. ${ }^{6}$ Hierdie beginsel word in soortgelyke terme by Aristoteles aangetref. ${ }^{7}$

Onder die Romeine was dit veral Cicero (106-43 v.C.) wat die Griekse, en meer spesifiek Plato se, geregtigheidsbegrip in Latyn weergegee het. Ook vir hom was geregtig-

2 Raadplceg Van Zyl Justice and Equity 39-42.

3 Van Zyl Justice and Equity 42.45.

4 Van Zyl Justice and Equity 45-47.

5 Die vernaamste bronne van Plato se regsfilosofic was sy Politeia (Republick) en Nomoi (Wette). Sy geregtigheidsbegrip word volledig behandel, met ruim verwysing na primêre en

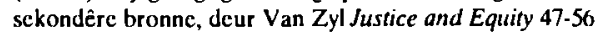

6 Politeia $331 \mathrm{E}$

7 In sy Thetorika 1.9.7 (1366b.). Oor geregtigheid in die algemeen by Aristoteles raadplecg Salomon Der Begriff der (jerechtigkeit; Trude Der Begriff der (jerechtigkeit; Van der Vyver Koers 1962:224-259; Du Plessis (LL.D proefskrif, PU vir CHO) 99-114; idem Westerse regsdenke tot en met die Middeleeue 106-114; Van Zyl Justice and Equity 56-70. 
heid (iustitia) 'n morele of etiese begrip eerder as 'n regsbegrip, soos daaruit blyk dat hy die primêre of kardinale deugde van Plato net so oorgeneem het. Naas geregtigheid het hy hierdie deugde beskryf as sapientia (wysheid) of prudentia (verstandigheid), fortitudo (dapperheid) en temperantia (matigheid). In sy bespreking van morele skoonheid en eerbaarheid (honestum) blyk dit dat die kern en wese van sy siening van geregtigheid van sowel Plato as Aristoteles afkomstig is, naamlik om aan elk te gee wat hom toekom (suum cuique tribuere). ${ }^{8}$ Van belang is dat die individu se regte skynbaar nie onbeperk is nie, maar onderhewig is aan die belange van die gemeenskap (communis utilitas). ${ }^{9}$

In die klassieke Romeinse reg was daar veral twee spreuke wat aan die geregtigheidsbegrip sy ewigdurende beslag gegee het, naamlik Celsus se definisie van reg as "die kuns van wat goed en billik is" (ius est ars bom et aequi) ${ }^{10}$ en Ulpianus se omskrywing van geregtigheid as "die voortdurende en ewige begeerte om aan elkeen sy eie reg te laat toekom" (iustitia est constans et perpetua voluntas ius suum cuique tribuere). ${ }^{11}$ Hierdie gedagte kom weer voor in sy omskrywing van regsvoorskrifte (iuris praecepta) as "om eerbaar te lewe" (honeste vivere), "om 'n ander nie kwaad aan te doen nie" (alterum non laedere) en "om aan elk te gee wat hom toekom" (suum cuique tribuere). ${ }^{12}$

Dit is opvallend hoe geregtigheid en billikheid (aequitas) in die na-klassieke Romeinse reg bykans sinoniem word, iets wat reeds blyk uit Celsus se gemelde definisie van reg (en dus ook van geregtigheid) as die ars boni et aequi. ${ }^{13}$ Dit hang waarskynlik saam met die groeiende belangrikheid van Christelike moraliteit of etiek betreffende die reg en regsbegrippe. ${ }^{14}$ Hierdie tydperk word gekenmerk deur die neiging om weg te beweeg van die gestrengheid van die reg deur aan geregtigheid en billikheid in alle

\footnotetext{
8 De finibus 5.23.65-66. Elders praat hy van dic waardigheid wat aan clk moet toekom: suam cuique tribuens dignitatem (De inventione 2.53.160). Oor geregtigheid by Cicero, raadpleeg Van Zyl Justice and Equity in Ciccro 104-147.

9 De inventione 2.53.160.

10 Aangehaal deur Ulpianus in D 1.1.1 pr.

11 D $1.1 .10 \mathrm{pr}$. Hicrdic definisic verskyn bykans woordeliks in Justinianus se Institute $1.1 \mathrm{pr}$.

12 D 1.1.10.1 Hierdic definisic kom ook voor in Inst Just 1.1.3.

13 Noot 10 hicrbo.

14 Kaser Das Römische Privatrecht 60-63.
} 
dinge voorkeur te gee, soos Keiser Konstantyn dit in 314 n.C. gestel het: Placuit in omnibus rebus praecipiam esse iustitiae aequitatisque quam stricti iuris rationem. ${ }^{15} \mathrm{Ek}$ dink nie dat dit vergesog sou wees nie om te sê dat die moderne begrip van menseregte in wese sy oorsprong het in die beginsel van suum quique tribuere wat deur Ulpianus, via Cicero, van die antieke Griekse filosowe, Plato en Aristoteles, oorgeneem is. Hierdie beginsel is sonder meer deur die Middeleeuse regsgeleerdes bekend as die glossatore aanvaar. ${ }^{16}$ Ook die beroemde teoloog. Thomas Aquinas, het met goedkeuring daarna verwys. ${ }^{17}$ Onder die Romeins-Hollandse regskrywers het Hugo de Groot goedkeurend verwys na Simonides as skepper van die gemelde beginsel. ${ }^{18}$ Voet verwys direk, en eweneens goedkeurend, na Cicero in hierdie verband. ${ }^{19}$ Uit al hierdie skrywers se geskrifte blyk dit verder dat daar 'n noue verband tussen geregtigheid en billikheid is. ${ }^{20}$

Noudat dit uit hierdie regsfilosofiese en regshistoriese resumé duidelik blyk dat die geregtigheidsbegrip van die antieke Griekse filosowe deel van die Romeinse reg en van die Romeins-Hollandse reg geword het, ontstaan die vraag of dit enigsins in die Suid-Afrikaanse regskonteks relevant is. ${ }^{21}$

15 C 3.1.8. Oor geregtigheid in Romeinse reg en regsdenke raadplecg Van Zyl Di Jlire 1\%90:110117

16 Bv. Rogerius Quaestiones super Institutis 1.4 aangehaal in Van Zyl Justice and Equity 209 n 892

17 In sy Summa theologiae 2.2.58.5. Dieselfde vind ons by Calvyn in sy Institutio religionis Christianae 3.7.3.

18 De iure belli ac pacis 2.11.1.5

19 Commentarius ad pandectas 1.1.11. Groenewegen De legibus abrogatis 1.1.3 verwys na die satirikus. John Barclay, wat in sy Satyricon 1 sĉ dat dic iuris praecepta van honeste vivere, alterum non lacdere en jus suum cuique tribuere definitief afgeskaf is. Dit is kennclik satiries bedoel na aanleiding van dic ontstellend ver anderende mores van dic mensdom. Dit blyk uit Groencwegen se kommentaar: Hactenus Barclayus eleganter atque satyrice in hominum dissolutos mores.

20 Oor billikheid as sodanig is 'n deeglike studic onlangs gedoen deur Du Plessis TR 1989:16-28. Vgl. Van Zyl De Jure 1986:110-131; idem SALJ 1988:272-290

21 Oor dic regsfilosofiese aspek raadplecg Van Zyl TR 1990:113-122 en vergelyk dic interessante bydrae van Sanders THRHR 1990:203-210. Die waarde van regsgeskiedenis as sodanig het reeds heclwat polemiek uitgelok. Een van die beginpunte is Van Zyl THRHR 1972:19-37, wie se metode krities bejecn word deur Visser The Legal Historian as Subversive or: Killing the Capitoline Geese" in D.P. Visser (ed.) Essays on the History of Law 1-31. Oor dic belangrikhcid van regsgeskiedenis is daar geen Iwyicl nie, soos aangedui deur R. Zimmermann Legal History: Does it Still Deserve its Place in the Curriculum? (Intreerede, Universitcit van 


\section{ROMEINSE REG EN DIE SUID-AFRIKAANSE GEMENE REG}

Romeinse reg speel 'n onmiskenbaar belangrike rol in die hedendaagse Suid-Afrikaanse reg, synde die fondament van die ius commune europaeum, die Europese gemene reg, wat gedurende die Middeleeue ontwikkel het en in onder andere die Nederlande geresipieer is. Prof. Erasmus sit hierdie rol skitterend uiteen in 'n bydrae oor Romeinse reg in die teenswoordige Suid-Afrika. ${ }^{22} \mathrm{Hy}$ wys daarop dat, in die hedendaagse 'radikale debat' oor die reg, dit soms aangevoer word dat 'n nuwe sosiale orde in Suid-Afrika tot stand moet kom en dat daar gekonsentreer moet word op die ontwikkeling van nuwe tegnieke eerder as om die 'steriele spitsvondighede' (sterile subtleties) van die verlede te kweek. Romeinse reg en regsgeskiedenis sou dan glad nie geskik wees om enige bydrae tot die nuwe orde te lewer nie en moet dus verwerp word. ${ }^{23}$ Volgens Erasmus word hierdie standpunt gebaseer op die een of ander sosiopolitiese ideologie, wat die gevolg het dat die hoofdebat draai om ideologie en nie om die waarde van Romeinse reg nie. Dit word ongelukkig nie deur die voorstanders van die nuwe reg aangedui hoe hulle van die verlede wil wegbreek nie. ${ }^{24}$

Oor die rol van Romeinse reg in die moderne Suid-Afrikaanse regspraktyk sê Erasmus dat dit toonaangewend is, aangesien dit een van die fondamente van ons reg is, selfs al word daar nie dikwels na Romeinsregtelike bronne as sodanig gekyk nie. In hierdie verband sê hy:

In evaluating the present and probable future position of Roman law in South Africa. we should be concerned therefore not with the practical application of detailed rules of $R$ oman law but with Roman law as a creative force in the cvolution of modern South African law. 25

Ek moet my by hierdie sienswyse aansluit. Die bestudering en dosering van Romeinse

Kaapstad, 1981). Vgl. Thomas De Jure 1989:275-283.

22 Erasmus $S A L J$ 1989:666-677. Dic herlewing van die Romeinse reg vanaf dic twaalfde eeu word uitvoerig beskryf in Van Zyl Geskiedenis van die Romeins-Hollandse Reg 1979:81-204, waarna die persepsie van Romeinse reg in veral Frankryk, Duitsland en Nederland bespreck word (205-419). Kyk onk Turpin Irish Jurist 1968:162-174.

23 Erasmus 671 . Kyk ook na die opmerkings in hierdic verband van Zimmermann op bladsy 2 van sy gemelde intrecrede (noot 20 hierbo).

24 Erasmus 671-672.

25 Erasmus 674.

Koers 57(1) 1992:3-29 
reg as sodanig is, in die Suid-Afrikaanse regskonteks, 'n ietwat steriele oefening. Dit is goed om ' $n$ inleidende kursus in Romeinse reg aan ons universiteite aan te bied, maar dit moet so spoedig moontlik by die student tuisgebring word dat dit siegs die eerste, dog onmisbare, stap in die ontwikkeling van ons gemene reg is. Dit moet geïllustreer word deur die aanbieding van capita selecta uit veral die sake- en verbintenisreg met gebruikmaking van oorspronklike bronne uit die verskillende stadia van ontwikkeling van die betrokke onderwerp. Dit spreek vanself dat die student wat in Latyn goed onderlê is, soveel makliker so 'n studie sal kan onderneem en met soveel meer vrug die lewendige groei van ons reg sal kan waarneem as die student wat nie aldus onderlê is nie. Dit is nie my voorneme om my weer oor die Latynpolemiek uit te laat nie. Ek het dit telkens reeds gedoen.26

Van groter belang, en inderdaad fundamenteel tot die bespreking van regsvernuwing in Suid-Afrika, is wat verstaan moet word onder die begrip gemene reg. Die begrip Romeins-Hollandse reg is, soos ek reeds in 1979 in my boek oor dié onderwerp aangetoon het, gans en al te beperk en verwarrend eerder as verhelderend. Ek het toe reeds die standpunt ingeneem dat ons gemene reg nie slegs die reg van die provinsie Holland is soos dit in die sewentiende en agtiende eeu bestaan het nie, maar inderdaad die gemene reg (ius commune) van Europa is, wat ontstaan het uit die Justiniaanse Romeinse reg en in verskillende dele van Europa, insluitende die Nederlande, ' lewendige ontwikkeling ondergaan het. $27 \mathrm{Ek}$ het ook daarop gewys dat die reg van Suid-Afrika eintlik gemeng of hibridies is, in dié sin dat dit nie slegs die Europese ius commune is wat hier te lande oorgeneem is nie, maar dat dit ook groot dele van die Engelse reg insluit. Daarom is dit korrekter om ons gemene reg as 'Suid-Afrikaanse gemene reg' te beskryf eerder as 'Romeins-Hollandse reg' of selfs 'Romeins-Europese reg. 28

26 Raadplecg Van Zyl THRHR 1990:229-234, waarin gepleit word vir die instelling van 'n eenvormige regslatynkursus met ruim verwysing na Romeinsregtelike en latere bronne. Kyk ook Scott De Jure 1989:335-343. Interessante standpunte oor hierdie onderwerp is ingeneem by die seminaar oor Latyn en regsopleiding wat op 21 Julie 1989 te UNISA, Pretoria onder dic vaandel van dic Klassieke Vereniging van Suid-Afrika gehou is. (Kyk Codicillus 31 (1990) 4-24.

27 Van Zyl Geskiedenis van die Romeins-Hollandse Reg 498-499.

28 Van Zyl 499-500. Kyk ook van Zyl 1981 Beginsels van regsvergclyking 279-296, waar SuidAfrika en Skotland as gemengde regstelsels behandel word. Dic gemengde regstelsel van Skolland word bespreck deur, onder andere, Smith Juridical Rev 1950:1-17; idem Juridical Rev 1959:119-141; idem Juridical Rev 1961:32-52; Stein Juridical Rev 1963:205-245; Mahe Juridical Rev 1977:21-37; McCall Smith Lesotho LJ. 1985: 283-293; Robinson, Fergus, Gordon European Legal History 1985:377-405. Bydraes oor dic gemengde regstelsel van Sri Lanka sluit in Chandrahasan Colombo L. Rev 1972:77-84; Peiris Colombo L Rev 1978:1-15 Weeramant ry Lesotho $L J$. 1985:135-164. Oor gemengde sisteme raadpleeg verder McKnight Juridical Rev 1977: 177-186. Dit moet opgelet word dat die Engelse reg self nic sonder 
Hierdie beskouing word ondersteun deur prof. Zimmermann in sy uitstekende studie van sintese in Suid-Afrikaanse privaatreg. ${ }^{29}$ Die sintese wat hy hier bedoel, is dié van die Romeinse reg, Engelse common law en wat hy beskryf as die usus hodiernus pandectarum. Hierdie interessante beskrywing slaan op die gebruik van die Europese ius commune (met insluiting van bronne wat buite die streng Romeins-Hollandse kader val) as reg wat in ooreenstemming met teenswoordige behoeftes aangepas en toegepas word. Hy lewer skerp kritiek op die sogenaamde 'puriste' wat alles wat Engelsregtelik is, wil uitroei. Die strewe moet eerder wees 'n sintese van hierdie regstelsels en hulle regsinstellings as om voortdurend 'n konflik tussen hulle te wil vind. Hieroor sê hy:

\begin{abstract}
It is lime, I think, Io leave hehind such prejudices, hased on historical misconceptoons and nationalistic narrowness. This applics not only in view of the necessity of legal harmonication in a modern Europe that is moving once again in the dircction of grcater political and conomic unity; it should also guide our approach to modern South African law. Thus. onc should concentrate onc's altention not so much on the distance and the differences between common law and civil law, but on their closeness and their resemblances. This implies the tracing of explicit as well as cryptic reception processes and a comparison of the legal solutions on the background and from the point of vicw of the development of a truly European civilization. ${ }^{30}$
\end{abstract}

In hierdie verband moet ek ongelukkig verskil van prof. Visser wat van die standpunt uitgaan dat daar geen bepaalde betekenis aan die begrip Romeins-Hollandse reg gegee kan word nie, sodat dit 'n regter vrystaan om die gemene reg te wysig en dus regsonsekerheid in die hand te werk. ${ }^{31}$ Hierdie standpunt spruit voort uit sy myns insiens verkeerde premisse dat die Romeins-Hollandse gemene reg van Suid-Afrika beperk is tot die reg van Holland, soos verkondig in die saak van Tjollo Ateljees (Edms) Bpk v

Romeinsregtclike beinvloeding ontwikkel het nic. Kyk Van Zyl 279-283 en verder Birks Inish Jurist 1971:147-162; Donahue Michigan L. Rev. 1983:972-976; Riescinfeld Lesotho L.J. 1985:267-281; Palmer Lesotho L.J. 1985: 317-329, Oor dic ius commune as sodanig kyk Coing Law Quanerly Rev. 1973: 505-517; Cairns Northern Ircland Law Quanerly 1981:272-283. Oor dic betckenis van die Romcins-Hollandsc reg vir Europa kyk dic onlangse bydrae van Zımmermann Junsten Zeitung 1990:825-838. Oor dic rescpsic-proses in Suid-Afrika kan gckyk word na dic onlangse bydraes van Kahn Lesotho $L J$. 1985:69-95 (met 'n bespreking van dic begrippe pragmatists, antiquarians, purists en pollutionists); Zimmermann Lesotho L.J. 1985:97-120; Ramsden Transkci LJ. 1986:91-10\%. Kyk ook Mostert Die Romeins-Hollandse Reg in oenskou (intreerede, Univcrsitcit van Pretoria, 1\%88); Lee Colombo L. Rev. 1969:1-11; Pauw TSAR 1980:32-46; Zimmermann Das Römisch.Hollandische Rech in Südafrika 1990:825-838; Spiller THRHR 1985:164-182

29 Zimmermann SALU 1986:259-289.

30 Zimmermann 276. Hierdic henadering word gesteun deur Erasmus $S A L J$ 1989::666-677.

31 Visser THRHR 1986:127-138. 
Small. ${ }^{32}$ Dit is dan verstaanbaar dat hy beswaar kan hê teen die wye interpretasie van Romeins-Hollandse reg soos dit uit verskeie beslissings van ons howe blyk.

Visser se standpunt word enigermate gesteun deur twee onlangse beslissings van die Appèlhof, te wete Du Plessis $N O$ v Strauss ${ }^{33}$ en Bank of Lisbon and South Africa Ltd v De Omelas and Another ${ }^{34}$. Op die ratio decidendi wat uit hierdie sake blyk, wil ek nie ingaan nie: dit is reeds ruimskoots gedoen. ${ }^{35}$ Wat vir die huidige gesprek van belang is, is dat die hof in albei sake 'n eng omskrywing van Romeins-Hollandse reg gee, naamlik die reg wat in die provinsie Holland gegeld het, maar tog blykbaar 'n heelwat wyer interpretasie daaraan gee. In die Bank of Lishon-saak word sekere reëls met betrekking tot die inhoud van geresipieerde reg in Holland neergelè. Twee professore van hierdie universiteit, proff. Olivier en Du Plessis, het in 'n uiters deeglike en uitstekend gemotiveerde vonnisbespreking die hof se houding oor die Romeins-Hollandse reg ten opsigte van albei sake ontleed en gekritiseer. ${ }^{36}$ Hulle wys daarop dat hierdie sake veel meer vrae laat ontstaan het as wat dit antwoorde verskaf het. Ek moet my eerbiedig by hulle kritiek aansluit, met die kwalifikasie dat dit verblydend is om op te merk hoe diepgaande en noukeurig regshistoriese navorsing deur die onderskeie howe gedoen is. ${ }^{37} \mathrm{Ek}$ doen respekvol aan die hand dat ons hoogste hof ' $n$ belangrike rol in die regsvernuwingsproses kan speel deur weg te beweeg van die beperkte en beperkende omskrywing van ons gemene reg en deur nader te beweeg aan die verrykende sintese waarna Zimmermann verwys.

Hoewel daar oor die presiese omvang en omskrywing van ons gemene reg meningsverskil bestaan, bestaan daar geen twyfel dat die tans geldende Suid-Afrikaanse gemene reg, hoe dit ook al omskryf sou word, nie vervangbaar is nie. Selfs 'n uitgesproke kritikus van groot dele van die Suid-Afrikaanse regsbedeling, prof. Albie Sachs, kan nie

\footnotetext{
32 1949(1) SA 856(A) op 865-866, aangehaal deur Visser 135.

33 1988(2) SA 105(A).

34 1988(3) SA $580(\mathrm{~A})$.

35 Oor die Du Plessis-saak kyk bywoorbeeld Visser, Hutchison SALJ 1988:619-636. Dic Bank of Lisbon-saak word bespreek deur, onder andere, Lambiris $S A L J$ 1988:644-651; Hawthornc, Thomas De Jure 1989:143-154; Van der Merwe, Lubbe, Huysteen SALJ 1989:235-242.

36 Du Plessis, Olivier De Jure 1988:371-382.

37 Kyk ook Braun v Blann and Botha N.N.O. and Another 1984 (2) SA 850 (A), bespreck deur Forsyth SALJ 1986: 513-522. Oor 'purisme' in die reg kyk nool 28 hierbo, waar relevante gesag aangchaal word.
} 
'n toekomstige bedeling sonder Romeins-Hollandse reg sien nie. 38 Hy het wel beswaar teen die begrip Romeins-Hollandse reg en verkies dat dit beskryf word bloot as SuidAfrikaanse reg. ${ }^{39} \mathrm{Ek}$ is geneig om met hierdie beswaar saam te stem, hoewel die gemeenregtelike aard van die Romeins-Hollandse reg die beskrywing daarvan as SuidAfrikaanse gemene reg regverdig.40

Dit is van belang om daarop te let dat ons buurlande in Suidjer-Afrika nie eenvoudig die Romeins-Hollandse reg as gemene reg oorboord gegooi het nie. In Lesotho, Botswana, Swaziland en Zimbabwe is dit steeds die geldende gemene reg en word dit voorsien dat dit in die toekoms die gemene reg sal bly. ${ }^{41}$ Oud-hoofregter Dumbutshena van Zimbabwe was sekerlik een van die knapste eksponente van die RomeinsHollandsregtelike tradisie, soos selfs 'n oppervlakkige oorsig van die afgelope klompie jare se Suid-Afrikaanse hofverslae sal bewys. Gelukkig is hierdie talentvolle regsgeleerde nie vir die Suider-Afrikaanse regsbedeling verlore nie.

\section{REGSVERGELYKING EN REGSPLURALISME}

Dit staan reeds vas, uit wat so pas gesê is, dat regsfilosofie, Romeinse reg en regsgeskiedenis 'n onmisbare rol te speel het in enige proses van regshervorming of regsvernuwing. Ons kyk nou kortliks na die belangrikheid van regsvergelyking in hierdie proses en sny dan die begrip regspluralisme in die Suid-Afrikaanse konteks aan.

Die feit dat ons gemene reg uit die ius commune van Europa ontstaan het, maak dit voor die handliggend dat daar met vrug na ander stelsels, wat hulle oorsprong in die ius commune gehad het, gekyk kan word om te bepaal of daar nie uit hulle regsontwikkeling vir ons iets aan te bied is nie.

38 Sachs 1989 The Future of Roman Dutch Law in a Non-Racial Democratic South Africa. Kyk ook Lamprecht Lesotho L.J. 1985:345-355

39 Sachs 7 .

40 Hierdie sentiment is vroeg reeds uitgedruk in die saak van $R . v$ Goseb 1956(2) SA 696 (SWA) op 698 .

41 Daar kan in hierdic verband verwys word na Poulter Jnl. of African Law 1969:127-144; Beardsley Jnl, of African Law 1970:198-202; Pain ClLSA 1978:137-167; Bennetl Zimbabwe L.J. 1982:147-161; Burman Lesolho LJ. 1985:25-45; Sanders Lesotho LJ. 1985:47-67; Molokommc Lesotho LJ. 1985:121-134; Mahomed Lesotho LJ. 1985:357-364. 
Daar moet natuurlik op 'n sistematiese en analitiese wyse te werk gegaan word, anders sal die resultate van 'n regsvergelykende studie maklik as lukraak en oppervlakkig beskou kan word. 'n Behoorlike regsvergelykende metode moet dus gevolg word. ${ }^{42}$ $\mathrm{Na}$ my oordeel is dit nodig, waar die regstelsels wat vergelyk word dieselfde of ' $\mathrm{n}$ soortgelyke historiese oorsprong het, om nie slegs op die horisontale vlak moderne regstelsels met mekaar te vergelyk nie, maar om ook na die historiese raakpunte, op die vertikale vlak, tussen sodanige stelsels te kyk. Indien dit gedoen word, kan daar uiters nuttige raakpunte tussen ons regstelsel en dié van ander lande gevind word. Dit kan besonder voordelig vir regshervorming of regsvernuwing wees. ${ }^{43}$ Hoe pas hierdie onderwerp in by regspluralisme? Die antwoord hierop hang saam met die feit dat die Suid-Afrikaanse gemene reg, soos ons reeds gesien het, as dualisties beskryf kan word vir sover dit in sowel die Romeins-Europese ius commune as die Engelse common law gegrondves is. Die ius commune is weer die basis van wat bekend staan as 'RomaansGermaanse' regstelsels, terwyl die common law die verskillende 'Anglo-Amerikaanse' regstelsels ten grondslag lê. Hierdie groepe regstelsels kan nuttig met mekaar vergelyk word, veral omdat hulle in die algemeen onder die vaandel van 'Westerse' regstelsels tuishoort 44

Soos reeds vermeld, bestaan daar in Suid-Afrika 'n aantal inheemse regstelsels wat naas die gemene reg gelding geniet en wat, net soos die gemene reg, in 'n voortdurende proses van groei en vernuwing verkeer. Die inheemse reg, wat somtyds tradisionele reg genoem word, is in 'n groot mate gewoonteregtelik van aard en leen hom, in die algemeen, nie geredelik tot regsvergelyking met sogenaamde Westerse regstelsels nie. Wat die vergelyking verder bemoeilik, is die feit dat die gewoontereg van stam tot stam of groep tot groep kan verskil. Tog is daar basiese punte van ooreenstemming, veral die algemene doelstelling om harmonie in die samelewing te handhaaf of te herstel, na gelang van die geval. 45

42 Dil word bespreek in Van Zyl Beginsels van regsvergelyking 1981:34-43; idem THRHR 1983:1. 13 , met verwysing na uitvoerige gesag.

43 Belangrike bydraes op hierdie gebied is gemaak deur Watson, die bekende Romanis en regsvergelyker. Kyk sy Legal Transplants; Cambridge L.J. 1974:313-336; The Making of the Civil Law; Sources of Law, Legal Change and Ambiguity; The Evolution of Law. Laasgenoemde word bespreek deur Hocflich Michigan L. Rev. 1987:1083-1094. Kyk ook dic prikkelende bydrae van Markesinis Modem L. Rev. 1990:1-21.

44 Hierdie begrip word bespreek in bydraes soos dié van Berman Harvard L. Rev. 1977:900-931 David Univ. of Cincinnati L. Rev. 1983:126-135; Smith, Weisstub (1983) The Westert Idea of Law. Oor die Romaans-Germaanse en Anglo-Amerikaansc rcgsfamilies raadpleeg Van Zyl Beginsels van regsvergelyking 56-211.

45 Allott "African Law" in J.D.M. Derrett An Introduction to Legal Systems 131-156 op 145. Kyk ook Sanders Lesotho LJ. 1985:47-67 op 56-57; Van Zyl Beginsels van regsvengelyking 275-278. 
'n Interessante aspek van die inheemse reg is dat dit in 'n pluralistiese samelewing duidelike tekens van beïnvloeding deur Westerse reg toon sonder om noodwendig daardeur onderdruk te word. 46 Volgens Bennett is dit moontlik dat die inheemse reg in Zimbabwe mettertyd met die gemene reg sal kan saamsmelt 47 Mahomed sê weer van Lesotho dat dit teoreties moontlik is om aan te voer dat die gewoonteregtelike inheemse reg histories as deel van die gemene reg beskryf kan word ${ }^{48}$ Saam met die gemene reg het dit ' $n$ belangrike rol om te speel in die evolusie van 'n effektiewe en relevante regsisteem in Lesotho en ook in ander Suider-Afrikaanse lande. Hy doen aan die hand dat hierdie andersins verskillende regstelsels positief op mekaar sal kan inwerk deur uiting te gee aan voortdurend veranderende sosiale en morele waardes en aan tegnologiese ontwikkeling. ${ }^{49}$ Dit is skynnbaar ook Sachs se siening waar hy praat van oorplantings van inheemse reg op die gemene reg in Suid-Afrika ten einde dit 'n ware Suid-Afrikaanse reg te maak. 50

Hierdie standpunte is nie so vergesog as wat dit op die oog af mag lyk nie. 'n Belangrike stap om die bykans geïsoleerde bestaan van inheemse reg in Suid-Afrika te beëindig is geneem deur die promulgering van die Wet op die Afskaffing van Spesiale Howe vir Swartes, No 34 van 1986. Terselfdertyd is voorsiening daarvoor gemaak dat 'n hof in sake tussen swartes, waarby inheemse gewoontereg ter sprake is, geregtelike kennis daarvan kan neem en dit kan toepas behalwe vir sover dit herroep of gewysig is of strydig is met die beginsels van openbare beleid (daar word gepraat van "staatsgedragslyn") of natuurlike geregtigheid. In hierdie verband word spesifiek bepaal dat

\footnotetext{
Belangrike algemenc werke oor die inhecmse reg is dić van Schapera (1946) The BantuSpeaking Tribes of South Africa; Olivicr, Olivier (Jnr.), Olivicr(1989) Die Privaatreg van die Suid-Afrikaanse Bantoetaalsprekendes; Bekker, Cocrtze (reds.) Seymour's Customany Law in Southern Africa. Bckendc werkc oor spesificke stamregtc sluil in l. Schapera (1938) $A$ Handbook of Tswana Law and Custom; Language (1943) Stamregering by die Thlaping. ' $n$ Interessante bydrac is verder dié van Van Niekerk Codicillus 1990:34-43.

46. Sanders 60 wys daarop dat die inhecmse reg buitengewoon gocd oorlecf het. Dic redes wat hy hicrvoor aanyoer is dat Europese invlocd aanvullend cerder as plasvervangend gewerk het tcrwyl dic inhecmse reg builengewoon valbaar is vir a anpassing en sponlane groci.

47 Bennetl Zimbabwe LJ. 1982: 147-166 op 149.

48 Mahomed Lesotho LJ. 1985:357-364 op 359.

49. Mahomed 361-363

5o Sachs The Future of Roman Duch Law in a Non-Racial Democratic South Africa 19.
} 
Ulima spes: regsvernuwing en regsidealisme

lobola, bogadi of dergelike gebruike aldus nie strydig is nie. ${ }^{51}$

Belangrike verdere mylpale in die vernuwingsproses ten opsigte van inheemse reg is die onlangse aankondigings deur die Minister van Justisie dat die swart egskeidingshof tot niet gemaak gaan word en dat die egskeidingshof 'n spesialishof gaan word waar alle gekwalifiseerde regspraktisyns - advokate en prokureurs - sal kan optree. Dit verteenwoordig 'n samesmelting van minstens 'n gedeelte van die inheemse familiereg met dié van die gemene reg en blyk 'n stap te wees in die rigting wat onlangs deur die Tanzaniese Wet op huwelike en egskeiding bewerkstellig is. ${ }^{52}$

Nog meer onlangs, naamlik op 8 Mei 1991, het die Minister aangekondig dat 'n spesialiteitskomitee in die lewe geroep gaan word om ondersoek in te stel na die harmoniëring van die Romeins-Hollandse gemene reg en inheemse reg. Die belangrikheid van hierdie aankondiging is waarskynlik nog nie behoorlik besef nie, omdat inheemse reg vir die meeste Suid-Afrikaanse regsgeleerdes 'n geslote boek is. Dit spreek vanself dat die regsvergelykende metode in die uitvoering van hierdie taak van deurslaggewende belang sal wees. Soos Prinsloo egter aandui, moet daar sover moontlik gepoog word om die inheemse reg te boekstaaf ten einde 'n mate van vereniging van die uiteenlopende bronne van inheemse gewoontereg te bewerkstellig. 53 Op hierdie wyse kan regsvergelyking in alle opsigte in 'n regspluralistiese milieu relevant word. 54

51 A anvanklik is hierdic reeling getref deur artikel 54A van die Wet op Landdroshowe. No. 32 van 1944, maar hierdie artikel is herroep deur artikel 1(1) van dic Wysigingswet op Bewyslewering, No. 45 van 1988, wat dic gemelde bepalings op alle howe van toepassing gemaak het. Kyk Kerr SALJ 1986:526-538; idem SALJ 1989:166-172; Prinsloo De Jure 1987:68-82; Bckkcr "The Influence of Recent Legislation and Constitutional Changes on the Application of African Customary Law", in Sanders The Intenal Confict of Laws in South Africa 25-38; Olivicr "The Judicial Application of African Customary Law" in Sanders 39-55.

52 Raadpleeg Read Jnl. of African Law 1972:19-39. Onlangse bydracs oor Suid-Afrikaanse in heemse familicreg sluit in dié van Cocrtze Bafokeng Family Law and Law of Succession en Labuschagne De Jure 1986:293-312. Kyk ook Prinsloo CILSA 1990:324-336; Mndaweni CILSA 1990:361-373.

53 Raadpleeg Sanders "The Role of Comparative Law in the Internal Conflict of Laws" in Sanders 57-70. Kyk ook dic interessante bydrae van Dlamini "The Future of African Customary Law" in Sanders 1-12.

54 Prinsloo TSAR 1989:420-428; idem TSAR 1990:605-621. Vgl. idem TSAR 1990:223-238; idem De Jure 1990:357-363. 'n Onlangse voorbecld van boekstawing van inhecmse reg is dié van dic kodifikasies van Zoeloereg. Kyk Bckkcr THRHR 1990:180-189. 


\section{REGSVERNUWING}

Daar is reeds verwys na die regsvernuwing wat vir die inheemse reg, met betrekking tot die gemene reg, in die vooruitsig gestel word. Ek wil nou graag verwys na enkele verdere voorbeelde van regsvernuwing wat tans plaasvind of wat beoog word.

\subsection{Instelling van 'n menseregte-akte}

In die eerste plek moet kennis geneem word van die voorgestelde menseregte-akte wat onder 'n nuwe grondwet in werking sal tree. Hierdie saak het die belangstelling van politici aan albei kante van die politieke spektrum gaande gemaak. Ek meen dat dit noodsaaklik is om die onderwerp so ver moontlik te depolitiseer en dit te beskou slegs: as ' $n$ belangrike stap vorentoe in die regsvernuwingsproses. 55 Die beskerming van menseregte, soos reeds vermeld in die bespreking van die oorsprong van geregtigheid. dateer terug na die antieke regsfilosofie en word saamgevat deur die beginsel van suum cuique tribuere. ${ }^{56}$ Die tersaaklike werkstuk van die Suid-Afrikaanse Regskommissie maak ruim gebruik van Romeinse reg. gemene reg en ander regshistoriese bronne, regsfilosofie en vreemde regstelsels. Die verwysing hierna is uiters relevant vir 'n behoorlike en volledige begrip van die aard en trefwydte van 'n menseregte-akte. Die kern daarvan is egter dat reg en geregtigheid teenoor almal moet geskied. 57

\subsection{Hervorming van die regspleging}

In die verslag van die Direkteur-Generaal: Justisie wat onlangs in die Parlement ter tafel gelê is, wys mnr. Noeth daarop dat die toeganklikheid van die geregshowe vir alle

55 Daar bestaan 'n onoorsigtclikc massa literatuur oor die onderwerp van menseregte en aktes van mensercgle. Onder dic bekendstes hier te lande kan genoem word Dugard (1978) Human Rights and the South African Legal Order; Forsyth en Schiller (1979) Human Rights: The Cape Town Conference. Kyk ook Boshoff TSAR 1990:697-713. Oor 'n menseregte-akte as sodanig radplecg Cilliers Obiter 1978:92.99; Van der Westhuizen, Viljocn (1988) A Bill of Rights for South Africa; Hund TRW 1989:45-64; Wiechers THRHR 1989:311-324; Du Plessis THRHR 1989:421-428; Sachs SAJHR 19)0:1-24 (kritics bespreck deur Brooks SAJHR 1990: 25-35); Dlamini TSAR 1991:154-160; Forsyth SAJHR 1991:1-23.

S6 Noot 8 hicrbo.

57 Dit is waarskynlik dat 'n konstilusioncle hof tot stand sal kom. Dit was dic doel van 'n konferensic gehou tc Magalicsburg op 1 tot 3 Februaric 1991 oor "A Constitutional Court for South Africa". Die debat word lans gevour oor die model wat vir die voorgestelde hof gebruik sal word. 
persone een van die vernaamste eise is wat aan die regspleging gestel word. Voorts sê hy:

Tocganklikhcid van dic howe behels mecr as bloot teorclicsc tocganklikheid. Dic idcaal is dat elke persoon daadwerklik daartoc in staat moet wees om hom tot die howe te wend vir beskerming of handhawing van sy regle. ${ }^{58}$

Daar is twee struikelblokke wat in die weg staan van verwesenliking van hierdie ideaal. naamlik, eerstens, die buitensporige koste van litigasie wat buite die vermoë van die gewone mens val en, in die tweede plek, die feit dat daar eenvoudig nie genoegsame mannekrag is om regsverteenwoordiging te verskaf aan derduisende persone wat nie daarsonder kan klaarkom nie. Dit behoef geen betoog nie dat hierdie omstandighede groot onreg in die hand kan werk en ons regsidealisme in 'n utopiese ideaal kan omskep.

Tog is cuar lig aan die einde van die tonnel, soos blyk uit die volgende voorbeelde van vernuwende optrede van die kant van die Departement van Justisie in die onlangse verlede.

- Die verskeidenheid howe vir klein eise wat vanaf 1985 ingestel is, het tot dusver die benarde posisie van Jan Alleman in siviele aangeleenthede aansienlik verlig. Dit was myns insiens ' $n$ briljante ingewing om sulke howe in die lewe te roep, en hulle funksionering kan nie anders beskryf word nie as hoogs suksesvol.

* 'n Ander belangrike maatreèl wat getref is om koste te beperk, was die instelling van 'n Reëlsraad vir Geregshowe in 1987. Bestaande uit deskundiges op die gebied van die siviele prosesreg, is een van sy hooftake om op die kwessie van regskoste in te gaan en om voorstelle te doen ten einde eenvormigheid en vereenvoudiging van die siviele regsproses te bewerkstellig. Dit sluit in voorstelle oor metodes om die afhandeling van siviele sake te bespoedig. Groot onreg word veroorsaak deur die feit dat sake maande en selfs jare lank kan sloer totdat die punt bereik word dat geeneen van die partye enige voordeel uit hulle litigasie kan trek nie. Die Engelse spreuk justice delayed is justice denied het juis betrekking op sulke omstandighede. As ek in hierdie verband my mening mag lug, sal ek twee faktore uitlig wat in sekere gevalle tot heelwat van die vertraging aanleiding gee. Die eerste is dat litigasie te geredelik aanhangig gemaak word sonder dat daar eers behoorlik en volledig op die feite en die regsposisie ingegaan word. Die tweede is

\footnotetext{
58 Direktoraat Justisie: Verslag 1 Julie 1989 tol 30 Junic 1990 hoofstuk 1 par. 1.3.
} 
dat regspraktisyns soms onvoorbereid hof toe kom en skielik probleme ontdek wat hulle noop om uitstel te vra. Die kliënt, wat hom aan die genade van sy regsverteenwoordiger oorlaat, moet die spit afbyt, ook kostegewys. In sulke gevalle behoort daar myns insiens baie strenger deur ons howe opgetree te word en moet oorweeg word, indien die omstandighede dit regverdig, om die betrokke regspraktisyn uit sy eie sak (de bonis propriis) vir die verkwiste koste aanspreeklik te hou.

* Op die gebied van die strafregspleging word daar eweneens belangrike hervormingsmaatreëls in die vooruitsig gestel. Die vernaamste hiervan hang saam met die regsverteenwoordiging van persone wat nie 'n advokaat of prokureur kan bekostig nie en verplig word om hulle eie verdediging waar te neem. In die hooggeregshof het die Staat pro deo-regshulp áansienlik uitgebrei en verbeter, maar die probleem is in die landdroshof, waar sulke regshulp nie beskikbaar is nie. Ten einde hierdie probleem te oorkom, het die Minister die Regshulpraad versoek om oorweging te gee aan die moontlike instelling van die amp van 'openbare verdediger'. In sy verslag, wat onlangs in die Parlement ter tafel gelê is, word gesê dat na raming slegs ongeveer $20 \%$ van die meer as twee miljoen beskuldigdes wat jaarliks in die howe teregstaan, deur regsverteenwoordigers bygestaan word. Meer as 100000 beskuldigdes, wat nie aldus bygestaan word nie, word jaarliks direkte gevangenisstraf opgelê. Hierdie skokkende situasie kan enigsins in die reine gebring word indien persone wat in die strafreg onderlê is, hoewel hulle nie oor dieselfde kwalifikasies as advokate of prokureurs hoef te beskik nie, teen 'n salaris as openbare verdedigers kan optree. 59

* 'n Opwindende nuwe ontwikkeling hang saam met die Wetsontwerp op Howe vir Kort Proses en Bemiddeling in Sekere Siviele Sake van 1991. Hierdie Wetsontwerp maak voorsiening vir die daarstelling van 'n alternatiewe dispuutbeslegtigingsprosedure oftewel bemiddelingsprosedure ingevolge waarvan bemiddelaars op informele wyse poog om in sekere siviele sake skikkings te bereik tussen die partye of om minstens die geskilpunte te beperk en te vereenvoudig. Indien die saak nie geskik word nie, kan die partye na keuse hulle geding in die landdroshof of in 'n alternatiewe forum, bekend as die 'hof vir kort proses', voortsit. In hierdie hof sal 'n 'beregter vir kort proses' voorsit. Dit spreek vanself dat hierdie nuwe prosedure aansienlik sal kan help om hofkoste te verminder en om vertragings in litigasie uit te skakel. ${ }^{60}$

59 Verslag van Regshulpraad vir dic Tydperk 1 April 1989 - 31 Maart 1990 hoofstuk 3. Kyk ook McOuoid-Mason An Outline of Legal Aid in South Africa; Stcytler The Undefended Accused; Chaskalson Consutus 1990:98-102.

60 Kyk Van Vuuren De Rebus 1990:275-278. 
In die hoofartikel van die jongste uitgawe van Consultus word melding gemaak van die lekemagistrate wat bykans $85 \%$ van alle strafsake asook sekere siviele sake in Engeland behartig. Hierdie persone ontvang basiese opleiding maar geen salaris nie behalwe onderhouds- en reistoelae. Hulle lewer'n vrywillige diens, gewoonlik deeltyds, terwyl hulle ander beroepe beoefen, of voltyds as hulle pensioenarisse is. Consultus doen aan die hand dat dit verreweg 'n beter proposisie is as die 'volkshowe' (people's courts) wat deur allerlei onreëlmatighede gekenmerk word en dikwels ongeregtigheid eerder as geregtigheid in die hand werk.

'n Stap in die rigting van lekeregsbeamptes in Suid-Afrika is die Minister van Justisie se onlangse aankondiging dat dit beoog word om groter status en betekenis aan die amp van vrederegter of 'n soortgelyke amp te verleen vir beslegting van minder ernstige, gedekriminaliseerde misdrywe. Dit sal 'n besondere geleentheid wees om meer lede van die publiek by die regspleging te betrek. ${ }^{61}$

* Die instelling van die amp van gesinsadvokaat ingevolge die Wet op Bemiddeling in Sekere Egskeidingsaangeleenthed ${ }^{62}$ was ongetwyfeld een van die ingrypendste hervormings op die gebied van die familiereg. Heelwat publisiteit is reeds hieraan verleen, en ek wil nie verder daaroor uitwei nie behalwe om te rapporteer dat die loodsprojek in Pretoria 'n reuse sukses was en dat daar reeds vanaf 1 Mei 1991 'n kantoor in Johannesburg geopen is. Die vooruitsigte is uitstekend dat ons binnekort ook in Kaapstad 'n gesinsadvokaat of meerdere gesinsadvokate sal hê. Die belange van minderjarige kinders uit gebroke of verbrokkelende huwelike word vooropgestel. Daar het vanuit alle oorde enorme belangstelling gekom, en ons is verstom oor die vrywillige hulp wat angebied word om die gesinsadvokaat se taak te vergemaklik.

Die bemiddelingsaspek kom ook al hoe meer op die voorgrond, en ons bespeur groter verantwoordelikheidsin by ouers ten opsigte van die belange van hulle kinders. Ook van die kant van die prokureursberoep word daar heelwat samewer-

61 Consultus 4 (April 1991) 4. Oor 'volkshowe' raadpleeg Van Niekerk De Jure 1988:292-305. Publicke betrokkenheid kan natuurlik ook deur ' $n$ juriestelsel bewerkstellig word. Daar is tans n lewendige debal oor hierdie aangeleentheid. Kyk Rood De Rebus 1990:749-754; Du Plessis Codicillus 1990:33-38. 'n Intercssante voorstel is dić van Van Loggerenberg De Rebus 1990:755-758. Algemene waarnemings oor 'n verbetering van dic sivicle prosesreg in SuidAfrika kom vanaf De Vos De Jure 1989:139-142. Volgens hom moet vernuwing op die AngloAmerikaanse ecrder as die Europese model geskoci word.

62 Wet. No. 24 van 1987 
king verleen. Dit mag die voorloper wees van bemiddeling in egskeidings- en familieregtelike aangeleenthede in die algemeen - 'n opwindende vooruitsig. ${ }^{63}$

\subsubsection{Hervorming van die substantiewe reg}

Ten slotte wil ek enkele opmerkings maak oor die regshervorming wat op die gebied van die substantiewe reg tans plaasvind en in die vooruitsig gestel word. Dit is bekend dat die Suid-Afrikaanse Regskommissie vanaf sy ontstaan reeds op verskeie aspekte van regshervorming toegespits is, insluitende die skepping van 'n nuwe grondwet en die daarstelling van ' $n$ handves vir menseregte. In aansluiting hierby het die Minister van Justisie op 8 Mei 1991 in die Parlement aangekondig dat 'n hele aantal spesialiteitsprojekkomitees in die lewe geroep gaan word om navorsing te doen oor al die belangrikste vakgebiede van ons reg. Hierdie komitees sal onder leiding van die Regskommissie funksioneer en beloof om 'n onskatbare bydrae tot die proses van regsvernuwing in Suid-Afrika te lewer.

Intussen is ons howe ook druk besig om van hulle kant te poog om die reg aan die gemeenskap se eise om geregtigheid en billikheid te laat voldoen. Ek wil hier slegs na twee voorbeelde verwys, naamlik die ontwikkeling van die leerstuk van geregverdigde verwagting (legitimate expectation) in die administratiefreg en die uitbreiding van die beginsel van openbare beleid (public policy) op verskeie gebiede van die reg.

In 'n paar woorde verwys die leerstuk van geregverdigde verwagting na die individu se verwagting dat hy sy kant van 'n saak mag stel, sodat geregtigheid teenoor hom kan geskied. Die beginsel is dat hy geregtig is om aangehoor te word alvorens enige beslissing wat hom nadelig kan tref, geneem word. ${ }^{64}$

6.3 Daar kan in hierdic verband verwys word na Scott MacNab, Mowatt De Jure 1987:41-52; Burman, Rudolph SALJ 1990:251-278; Scott MacNab De Jure 1986:313-324. Oor dic moontlikhcid van gesamentlike beheer en toesig, kyk dic intcressante bydrae van Schafer SAL 1987:149-164.

64 Bcukes THRHR 1991:150-157. Dic lecrstuk is dcur Lord Denning in England op dic kaart geplaas in Schmidt and Another $v$ Secretary of State for Home Affairs (1969) 2 Ch 149 (CA); (1969) 1 All ER 904. In Suid-Afrika is dit toegepas in sake soos Everett v Minister of the Interior 1981(2) SA 453 (C) op 457; Metal \& Allied Workers Union v Castell N.O. 1985(2) SA 280 (D) op 286 F; Administrator, Transvaal, and Others v Traub and Others 1989(4) SA 731 (A). Raadplecg verder Hlophe SALJ 1987:165-185; Grogan SAJHR 1990:36-47; Carpenter Consultus 1990:59-61; Forsyth SALJ 1990:387-400; Barric TSAR 1991:169-173; Raath THRHR 1991:(0)-95. Vgl. idem THRHR 1990: 464-487 op 482-485. 
Begrippe soos openbare belang (public interest) en openbare beleid het ook in die afgelope tyd die regswêreld se verbeelding aangegryp. Dit is in die besonder uitgelig in 'n onlangse voordrag, gehou deur hoofregter Corbett, waarin daar gekyk is na die rol van openbare beleid in die ontwikkeling van ons gemene reg. ${ }^{65}$ Ek wil graag enkele dicta uit sy rede uitlig. So, byvoorbeeld, met verwysing na die rigtinggewende beslissing oor onregmatige mededinging in Schultz $v$ Butt ${ }^{6}$, sê die geleerde hoofregter:

So here again, where unlawful compctition is alleged and the case docs not fall within one of the recognized categories of unlawfulness, the court is required to take a policy decision: a decision orientated by considerations of fairness and honesty, but at the same time guided by boni mores and the general sense of justice of the community. ${ }^{67}$

Die klem val in hierdie dictum op die gemeenskap se sin vir geregtigheid, billikheid en die goeie sedes (boni mores), wat sy oorsprong in die antieke regsfilosofie vind en daarna in die Romeinse reg en in elke verdere stadium van ons regsgeskiedenis aangetref word.

Later in die rede, na die bespreking van 'n aantal verdere beslissings. word hierdie beginsels gekoppel aan wat gennem word die 'algemene maatstaf van redelikheid':

You will have noticed in my exposition of these decisions recurrent reference to concepts such as public policy, boni mores, the norms of conduct required by society, the legal convictions of the community, the general standard of reasonableness and so on. These are the crituria to be applied when the court is confronted with a Iegal problem in the common law for which there is no precedent or aulhority and where the judge has thus to step into the unknown; or when the court is asked to depart from common law precedent and strike out in a new direction. ${ }^{18}$

Hierdie verhewe gedagtegang word voortgesit in 'n aangrypende rigtingwyser vir elke regsgeleerde wat die ideaal van reg en geregtigheid nastreef:

(T)he policy decisions of our courts which shape and, at times, refashion the common law mus also reflect the wishes, often unspoken, and the pereeptions, often but dimly discerned, of the people. A community has certain common values and norms. These are in part a heritage from the past. To some extent too they are the product of the influence of other communities; of the interaction that takes place between peoples in all spheres of human activity; of the sayings and writings of the philosophers, the thinkers, the leaders, which have universal human appeal; of

\footnotetext{
65 Corbett SALJ 1987:52-69.

66. $1986(3)$ SA 667 (A) op 679 B-E.

67 Corbett 62. Kyk ook Van Heerden THRHR 1990:151-160.

6K Corbett 67
} 
the living example which other societies provide. It is these values and norms that the judge must apply in making his decision. And in doing so he must become the living voice of the people'; he must 'know us better than we know ourselves'; he must interpret society to itself.

In this process the judge would no doube be influenced by concepts of natural law, by international law norms and by the way in which the particular problem is handled in other comparable systems of jurisprudence. He would draw upon his knowledge and expericnco gained as an educated. responsible and enlightened member of society, upon the contact with and insight into his fellow humans which his professional carcer has given him; and he would draw upon his continuing perceptions of the attitudes of the community around him. And here it is of paramount importance that socicty should be frec; that there should be freedom of cxpression and the communicalion of ideas, an uninhibited press. For otherwise how is the judge to know what socicty is thinking? ${ }^{69}$

Die boodskap wat hieruit herlei kan word, is dat die howe kennis moet neem van die gemeenskapsopvatting of openbare beleid, selfs al beteken dit dat hulle lank gevestigde regsheginsels moet wysig of verwerp ten einde aan sodanige opvatting of beeld gestalte te gee. Dit is egter nie 'n willekeurige of diskresionêre besluit wat geneem word nie, maar een wat die regsposisie in ooreenstemming bring met die eise van geregtigheid, billikheid, redelikheid en goeie trou - almal eienskappe wat ten grondslag lê van 'n vreedsame, geordende, stabiele gemeenskap en wat aan sy hoogste morele eise voldoen. 70

\footnotetext{
69 Corbetl 67-(88.

70 Thusı Bank van Afrika Bpk. v Presiden Versekeringsmaatskappw Bpk. cn 'n Ander 1988 (1) SA 546 (W) op 552 E-(i. Kyk ook Randbank Lid. v Rubenstcin 1081(2) SA 207 (W) op 215 D.H Magna Alloys and Research (SA) (Pty) Lid. v Ellis 1984 (4) SA 874 (A): Sasfin (Pty) Lid. v Benkes 1989 (1) SA 1 (A) op 8 C.D; Edonard v Administrator, Natal 1989 (2) SA 368(D) op 378 E; Jordan and Another v Penmill Invesiments CC and Another 1991 (2) SA 430 (E); Siber Engineering Services (Pty) Lid. v Van Wyk and Another 1991 (2) SA 482 (T). Raadplceg ook Lubbe Stell L. Rev. 1990:7-25, wat die volgende sé (op 24): "'n Verfyning van die bona fides. begrip tot 'n norm wat redelik agling vir dic belange van 'n konıraklerende tecnparly vereis en dic erkenning dal dic handhawing van hierdic eis in die openbare belang is, bied die formelc meganisme waarlangs kontraksonbillikheid binnc dic beslaande analiticse struktuur van ons reg luisgebring kan word, hetsy deur middel van regicrlikc beslissings, hetsy deur middcl van welgewing." Kyk ook Van der Merwc, Lubbc Siell L. Rev. 1991: 91-101, waarin verwys word na 'n aantal verdere beslissings van ons howe. Oor dic rol van gocic trou in die VSA kyk Summers Comell L. Rev. 1981-1982:810-840 (met verwysing na artikel 205 van die Restatement (Second) of Contracts (1981), deur dic skrywer beskryl (op 810) as "one of the (ruly major advances in American conlracl law during the past fifty years"). Vgl. Wilton Juridical Rev. 1943:65-88. 'n Inleressantc onlangsc bydrac oor dic redelikhcidskriterium is dic van Heyns SALJ 1990: 279-303. Myns insiens kan redelikheid nie geskei word van die begrippe ycregtigheid, billikheid, goeie tron cn boni mores nic. Kyk my bydrac SALJ 1988: 272-290. Oor openbare belang op ander Icrreine raadplecg Du Plcssis Reg op inligting en die openhare belang (LL.D procfskrif, PU vir CHO); Prelorius Die begrip openbare belang en burgervryheidsbeperking (LL.D proefskrif, UOVS); Vgl. Habcrlc Öffentiches Interesse als juristisches Problem: Eine Analyse von Gesetzgebung und Rechtsprechung; Schultc (1970)
} 


\section{SLOTOPMERKING}

By die aanvang van hierdie artikel het ek gestel dat my boodskap een van optimisme en idealisme is. Ek vertrou dat hierdie oorsig van regshervorming en regsvernuwing my optimisme kon regverdig en die idealisme as regsidealisme in sy gepaste perspektief kon plaas. Ek is daarvan oortuig dat die regsvernuwing 'n vergestalting van ons regsidealisme sal wees indien dit ons almal se erns sou wees om reg en geregtigheid teenoor almal te laat geskied. Kry ons dit reg, het ons die hoogste verwagting, die ultima spes, bereik.

\section{BIBLIOGRAFIE}

ALLOTT. A.N. 1968. African Law. (In Derrelt, J.D.M. ed. An Introduction to Legal sistcms. London Sweet \& Maxwell.)

BARRIE, G.N. 1991. Legitimate Expectation and the Appeal Court - Where does inc ( incept Come From? TSAR, 169-173.

BEARDSLEY. J.E. 1970. The Common Law in Lesotho. Joumal of African Law, 198-21)

BEKKER. J.C. \& COERTZE, J.J.J, 1982. Scymour's Customary Law in Southern Airled Kalapstad : Juta.

BEKKER, J.C. 1990. The Influence of Recent Legislation and Constitutional Changes un the Application of African Customary Law. (In Sanders A.J. $e d$. The Internal Conflict of Laws in Soulh Africa. Durban : Bultcrworths. p. 25-38.)

BEKKER, J.C, 1990. The Two Ncw Codes of Zulu Law. THRHR, 180-189.

BENNETT, J.A. 1982. The Legal System of Zimbabwe. Zimbahwe LJ, 147-161

BERMAN, H.J. 1977. The Origins of Western Legal Science. Han ard L. Rev, 120-135

BEUKES, M. 1991. Geregverdigde verwagting as aanspraak van dic individu in dic administratiewe proses. THRHR, 150-157.

BOSHOF, A. 1990. Menseregte: 'n Afrika perspektief. TSAR, 697-713.

BROOKS, D.H.M. 1990. Albie Sachs on Human Rights in South Alrica. SAJHR, 25-35

BURMAN, S.B. 1985. How Roman Dutch Law became the Common Law of Lesotho. Lesotho L.J, 25 . 45 .

BURMAN, S \& RUDOLPH, D. 1900. Repression by Mediation: Mcdiation and Divorce in South Africa. SALJ, 251-278.

CAIRNS, J.W. 1981. Comparative Law, Unification and Scholarly Creation of a New lus Communc. Nonhen Ireland Law Quanerly, 272-283.

CHANDRAHASON, N. 1972. Roman Dutch Law in Ccylon. Colombo L Rev, 72-84.

CILLIERS, A.C. 1978. A Bill of Rights for South Africa. Obiter, 92-99.

COERTZE, R.D. 1988. Bafokeng Family Law and Law of Succession. Pretoria : Sabra

COING, H. 1973. The Roman Law as lus Commune on the Continent. Law Quarterly Re'v. 505-517.

CORBETT, M.M. 1987. Aspects of the Role of Policy in the Evolution of our Cummon Law. SALJ, 52 69.

Eigennum und öfentliches Interesse. 
DAVID, R. 1983. On the concept of Western Law. Univ. of Cincinnalti L. Rev, 126-133

DE VOS, W. 1989. Die hervorming van die SA sivicle prosesreg vanuit 'n teoretiese perspekticf. De Jure $139-142$

DLAMINI, C.R.M. 1990. The Future of African Customary Law. (In Sanders A.J. ed. The Internal Conflict of Laws in SA. Durban : Buttcrworths. p. 1-12.)

DLAMINI, A.M. 1991. The Pre-Conditions for a Bill of Rights. TS,4R, 154-160).

DONAHUE, C. 1983. Roman Influence on the Civil Law. Michugan L. Rev, 972-976.

DUGARD, J. 1978. Human Rights and the South African Legal Order Princeton : University Press.

DU PLESSIS, L.M. 1978. Dic juridiese relevansic van Chrsstelike getegtigheid. Potchefstruom. (Proefskrif (LL.D) - PU vir CHO.)

DU PLESSIS, L.M. 1981. Westerse regsdenke tot cn met dic Middelecue. Potchefstroom : Pro Rege.

DU PLESSIS, L.M. 1989. Glosses to the Working Papel vi ine SM Law Commission. IHRHR, 421-428.

DU PLESSIS, R. 1990. Die werking en belang van dic juriesselsel Codicillus. 33-38.

DU PLESSIS, W. 1986. Reg op inligling cn dic opentart belang. Potchefstroom (Procfskri! (LL.D.) PU vir CHO.)

DU PLESSIS, W. 1989. Acquilas-Equity-Billigkeit and the lisus Hodicrnus Pandectarum. TRH' 16-28.

DU PLESSIS, W. \& OLIVIER, N.J.J. 19gs' Du Plessis i Straus, Banh ol Lisbon and South Airica Lid । De Ornclus, De Jure, 371-382.

ERASMUS, H.J. 1989. Roman Law in South Alrica Today SALJ (606-677.

FORSYTH, C. \& SCHILLER, X. 1979. Human Rights: The Cape Town Conference. Kaapstad. Jutid.

FORSYTH, C. 1980. The Juristic Basis of the Temporary Trust. SALJ, 513-522.

FORSYTH, C. 1991. Interpreting a Bill of Rights: A Fuiurc Task ol a Reformed Judiciary? SAJHK. 513-522.

GROGAN, J. 1990. When is the 'Expectalion' of a Hearing Legitimate'? SAJHR. 36-47

HAWTHRONE, L, \& THOMAS, PH.J. 1989. The Excepio doli De Jure, 143-154.

HEYNS, C. $19 \% 0$. Reasonahleness in a Divided Socicly. SALJ. 279-303

HLOPHE, J. 1987. Legitimate Expectation and Nalural Justice. Englısh. Ausiralian and South African Law. SALJ, 165-185.

HOEFLICH, M.H. 1987. Law, Socicly and Reccplion: The Vision of Alan $W$ alson. Michigan L. Rev 1083-1094.

HUND, J. 1989. A Bill of Rights for SA. TRW, 45-64

KAHN, E. 1985. The Reception and Development of Roman Dutch Law in South Africa. Lesotho LJ. 69.95.

KASER, M. 1975. Das Römische Privaltrechı. Munchen : C.H. Beck.

KERR, AJ. 1986. Customary Law in Magistrates' Court and in the Supreme Court. SALJ, 526-538.

KERR, AJ. 1989. Customary Law in All Courts. SALJ, $16(6-172$.

LABUSCHAGNE, J.M. 1986. Regspluralisme, regsakkulturasie en dic onderhoud van kinders in dic inhecmse reg. De Jure, 293-312.

LAMBIRIS, M.A. 1988. The exceplio doli gencralis: an obiluary. SAL, (144-651.

LAMPRECHT, J.C. 1985. The Future lies in the Past. Lesotho L. J, 345-355.

LANGUAGE, F.J. 1943. Slamregering by die Thlaping. Stellenbosch : Pro Ecclesia Drukkery

LEE, R.W. 1969. The Roman Dutch Law in South Africa: Ihe Influence of English Law. Colombo L. Rev, 1-11.

LUBBE. G. 1990 . Bona-fides, billikheid en die openbare belang in die Suid-Afrikaanse Kontraktcreg Stell L. Rev, 7.25.

MAHER, (i. 1977. The Identity of the Scottish Legal Systcm. Juridical Rev, 21-37.

MAHOMED, 1. 1985. The Future of Roman Dutch Law in Southern Africa, particularly in Lesotho. Lesotho L. J, 357-364

MARKESINIS, B. 19\%. Comparative Law - a Subject in Search of an Audience. Modem L. Rev, 1-21. 
McCALL SMITH, R.A.A. 1985. Scots Law - Another Mixed System. Lesotho LJ, 283-293. McKNIGHT, J. 1977. Some Historical Observations on Mixed Systems of Law. Juridical Rev', 177-186. McQUOID-MASON, D.J. 1982. An Outline of Legal Aid in South Africa. Durban : Butterworths. MNDAWENI, C. 1990 . African Marriages still at the Crossroads in South Africa. CIL.5.4, 361-373. MOLOKOMME, A. 1985. The Reception and Development of Roman-Dutch Law in Botswana Lesotho L.J.121-134

MOSTERT, D.F. 1968. Dic Romeins-Hollandse Reg in ocnskou. (Intreercde, Universitcit van Pretoria) OLIVIER, N.J.J. 1990. The Judicial Application of African Customary Law (In Sanders A.J. ed. The Internal Conflict of Laws in South Africa. Durban : Butterworths. p. 39-56.)

OLIVIER, N.J.J., OLIVIER, N.J.J. \& OLIVIER, W.H. 1989. Dic Privaatrcg van dic Suid-Afrikaanse Bantoetaalsprekendes. Durban : Butterworths

PAIN, J.A. 1978. The Reception of English and Roman Dutch Law in SA with Reference to Butswana, Lesotho and Swaziland, CILSA, 147.167.

PALMER, V. 1985. Common Lawyers as Civilian Intermediaries: The Influence of Roman Law and Civil Law in England and the United States. Lesotho LJ, 317-329.

PAUW. P. 1980. Die Romuins-Hollandse Reg in ocnskou. TSAR, 32-46.

PEIRIS, G.L. 1978. The Legal System of Sri Lanka: Some Problems and Solutions. Colombo L. Rer, 1 15.

POULTER, S. 1969. The Common Law in Lesotho. Lesotho L.J. 124-144

PRETORIUS. J.L. 1986 Dic begrip openbare belang en burgervryheidsbeperking. Bloemfontein. (Procfskrif (LL.D.) - UOVS.)

PRINSLOO, M.W. 1987. Die nut geintegrecrde hofstelscl en die toepassing van die inhucmse reg. De Jure, $68-82$.

PRINSLOO, M.W. 1989. Belangrikheid van bockstawing van dic inhecmse reg. TSAR, 42X-429.

PRINSLOO, M.W. 1990 . Veldwerkmetodick in dic inhecmse reg. TSAR, 223-238.

PRINSLOO, M.W. 1990 . Regspluralisme, 'n menseregteakte en dic interne aanwysingsreg. De Jure, 357 363.

PRINSLOO, M W. 1991). Pluralism or Unification in Family Law in SA. CILSA, 324-33,

RAATH, A.W.G. 1990. Audi Alteram Partem in dic Suid-Afrikaanse Administratiefreg: 'n Uitweg uit 'n doolhol? THRHR, 464-487.

RAATH. A.W.G. 1991. Audi Alteram Partem: Is ons nou op die pad na Legitimate Expectation? THRHR, 90-95.

RAMSDEN, W.A. 1986. Our Legal Heritage. Transkei L.J, 91-106.

READ, J.S. 1972. A Milestone in the Integration of Personal Laws: Tanzania. Joumal of African Law, 19-39.

RIESENFELD, S.A. 1985. The Impact of Roman Law on the Common Law System. Lesotho LJ, 267. 281 .

ROBINSON, OF., FERGUS, T.D. \& GORDON, W.M. 1985. An Introduction to Europcan Legal History. Glasgow : Professional Books.

ROOD, L. $19 \% 0$. A Relurn Io the Jury System? De Rebus, 749-754.

SACHS, A. 1989. The Future of Roman Dutch Law in a Non-Racial Democratic South Africa: Some Preliminary Obscrvations. Ongepubliseerd.

SACHS, A. 1990 . Towards a Bill of Righis in a Democratic SA. SAJHR, 25-35.

SANDERS, A.J.G.M. 1985. Legal Dualism in Lesotho, Botswana and Swaziland Lesolho LJ, 47-67.

SANDERS, A.J.G.M. 199). The Role of Comparative Law in the Internal Conflict of Laws. (In Sanders ed. The Internal Conflict of Laws in South Africa. Durban : Butterworths. p. 57-66.)

SANDERS, A.J.G.M. 1990. Legal Philosphy as a Political Tool in South Africa. THRHR, 203-210.

SCHAFER, I. 1987. Joint Custody. SALJ, 149-164. 
SCHAPERA, I. 1938. A Handbook of Tswana Law and Custom. London : New Impression. SCHAPERA, I. 1946. The Bantu-Speaking Tribes of South Africa. London: Roulledge \& Paul. SCOTT, J. 1989. Verpligte Latyn vir die advokaat: 'n Plcidooi om behoud. De Jure, 335-343. SCOTT MACNAB, D. \& MOWATT, J.G. 1986. Medation and Arbritation as Altcrnative Procedures it Maintenance and Custody Dispute in the Event of Divorec. De Jure, 313-324.

SCOTT MACNAB, D. \& MOWATT, J.G. 1987. Family Mediation - SA's awakening Interest. De Jure, 41-52.

SCHULTE, H. 1970. Eigentum und offentliches Interessc. Berlin : Dunckcr \& Humblot.

SMITH, T.D. 1950. The Durability of the Scottish Legal Tradition. Juridical Rer, 1-17.

SMITH, T.D. 1959. Strange Gods: The Crisis of Scots Law as a Civilian System. Juridical Rev, 119-141.

SMITH, T.D. 1961. Scots Law and Roman Dutch Law. Shared Tradition. Juridical Rev, 32-52.

SMITH, J.C. \& WEISSTUB, D.N. 1983. The Western Idca of Law. Durban : Butlcrworths.

SPILLER, P.R. 1985. The Romodutchyafricanderenglander Law of Ninetcenth-Century Natal. THRHR. $164-182$.

STEIN, P. 1963. The Influence of Roman Law on the Law of Scolland. Jundical Rev, 205-245.

STEYTLER, N.C. 1988. The Undefended Accused on Trial. Ka:apstad : Juta.

STEYTLER, N.C. 1\%). The Undefended Accused. Consultus. 98-112.

SUMMERS, R.S. 1981-1982. The (iencral Duty of Good Faith - Its Recognition and Conceptualization Comcll L. Rev, 810.840.

THOMAS, J. 1989. Method and Aim of Legal History. De Jurc. 275-283.

TRUDE, P. 1955. Der Begriff der (Gerechligkeit in der Aristotelischen Rechts. Berlin : Neuc Kolner Abhandlunger.

TURPIN, C.C. 1968. The Reception of Roman Law. Irish Jurist, 162-174.

VAN DER MERWE, S., LUBBE, G. \& Huyssiecn, L.F. 198\%. The exceptio doli generalis. SALJ. 235242.

VAN DER MERWE, S. \& LUBBE, (;. 1991. Bona-Fides and Public Policy in Contract. Sicll L. Rei, 91 . 101.

VAN DER VYVER, J.D. 1\%62. Die regslecr van Aristoteles. KOERS, 29(9\& 10):224-250.

VAN DER WESTHUIZEN, $J$. \& VILJOEN, H. 1988. A Bill of Rights for South Africa. Durban Butterworths.

VAN HEERDEN, H.J.O. 1990. Dic mededingingsprinsicp en dic boni mores as onregmaligheidsnorme by onregmatige mededinging. THRHR, 151-160.

VAN LOGGERENBERG, D.E. 1990. A Ouccn's Bench Master for SA. De Rebus, 755-758.

VAN NIEKERK, G.J. 1988. Peoples' Court and Pcoples' Justice in SA. De Jure, 292-305.

VAN NIEKERK, G.J. 1990. Indigenous Law in SA - A Historical and Comparative Perspective. Codicillus, 34-43.

VAN VUUREN, A.L.J. 199). Alternaticwe dispuutbeslegting. De Rebus, 275-278.

VAN ZYL, D.H. 1972. Dic regshistoricsc melode. THRHR, 19-37.

VAN ZYL, D.H. 1979. Geskiedenis van die Romeins-Hollandse Reg. Durban : Butterworths.

VAN ZYL, D.H. 1981. Beginsels van regsvergelyking. Durban : Butterworths.

VAN ZYL, D.H. 1983. Die regsvergelykende metode. THRHR, 1-13.

VAN ZYL, D.H. 1986. Aspekse van billikbcid in die reg en regspleging. De Jure, 101-131.

VAN ZYL, D.H. 1988. The Significance of the Concepts 'Justice' and 'Equity' in Law and Legal Thoughts. SALJ, 272-290.

VAN ZYL, D.H. 1990. Anticke regsfilosofic in perspekticf. TRW, 11.3-122.

VAN ZYL, D.H. 1990. Justice in Roman Law and Legal Thought. De Jure, 110-117

VAN ZYL, D.H. 1990. Is juridiesc harbarisme ons voorland? THRHR, 229-234.

VAN ZYL, D.H. 1991. Juslice and Equity in Cireek and Roman Legal Thought. Pretoria : Academica. 
VAN ZYL, D.H. 1991. Justice and Equity in Cicero. Pretoria : Academica.

VISSER, D.P. 1986. Deadalus in the Supreme Court - The Common Law Today. THRHR, 127-138.

VISSER D.P. 1989. The Legal Historian as Subversive or: Killing the Capitoline Geese. ( $n$ D.P. Vissc ed. Essays on the History of Law. Kaapstad : Juta. p. 1-31.)

VISSER, D.P. \& HUTCHINSON, D.B. 1988. Legislation from the Elysion fields: the Roman Dutch Authorities Settle an old Disputc. SALJ, 619-636.

WATSON, A. 1974. Legal Transplants. Charlottesville : University Press of Virginia

WATSON, A. 1985. Sources of Law, Legal Change and Ambiguily. Oxford : Blackwell

WATSON, A. 1985. The Evolution of Law. Oxford : Blackwell.

WEERAMANTRY, C.G. 1985. The Reception and Development of the Roman Dutch Law in Sri Lanka. Lesotho $L J, 135-164$.

WIECHERS, M. 1989. 'n Monument in SA rcgsontwikkcling? Groeps- en menseregte. THRHR, 311 324.

WILTON, G.W. 1943. Faith: Foundation of Law. Juridical Rev, 65-88.

ZIMMERMANN, R. 1981. Legal History: Does it still Deserve a Place in the Curriculum? (Intrecrede. Universiteil van Kaapland).

ZIMMERMANN, R. 1983. Das Romisch-Hollandische Recht in Südafrika: Einfuhrung in dic Grundlagen und usus hodicrnus. Darmstadt : Wissenschaft liche Buchgesellschaf!

ZIMMERMANN, R. 1985. Roman Dutch Law in South Africa: Aspects of the Reception Process. Lesotho LJ, 97-120.

ZIMMERMANN, R. 1986. Synthesis in South African Private Law: Civil Law, Common Law and Usus Hodiernus Pandectarum. SALJ, 259-289.

ZIMMERMANN, R. 1990. Das Romisch-Hollandische Recht und scine Bedeutung fur E uropa. Juriste Zeitung, 825-838.

\title{
WETTE
}

Wet op die Afskaffing van Spesiale Howe vir Swanes, No. 34 van 1986

Wet op Bemiddeling van Sekere Egskcidingsaangeleenthede, No. 24 van 1987

Wet op Landdroshowe, No. 32 van 1944

Wysigingswet op Bewyslewering, No. 45 van 1988

\section{HOFSAKE}

\author{
Administrator, Transvaal and Others v Traub and Others 1989 (4) SA 731 (A) \\ Bank of Lisbon v De Omelas 1989 (3) SA 580 (A) \\ Broun v Blann and Botha N.N.O. and Another 1984 (2) SA 850 (A) \\ Du Plessis v Strauss 1988 (2) SA 105 (A) \\ Edouard v Administrator, Natal 1989 (2) SA 368 (D) op 378 E \\ Everett $v$ Minister of the Interior 1981 (2) SA 453 (C) op 457 \\ Jordan and Another v Penmill Invesiments CC and Another 1941 (2) SA 430 (E) \\ Magna Alloys and Research (SA) (Pry) Lid. v Ellis 1984 (4) SA 874 (A) \\ Metal \& Allied Workers Union v Castell N.O. 1985 (2) SA 280 (D) op 286 F \\ Randbank Ltd. v Rubenstein 1981 (2) SA 207 (W) op 215 D-H \\ $R \vee$ Gaseb 1956 (2) 696 (SWA) op 698 \\ Sasin (Pty) Led v Beukes 1989 (1) SA I (A) op 8 C-D \\ Schmidt and Another $v$ Secretary of State for Home Affairs 19692 Ch 149 (CA)
}


Schultz v Butt 1986 (3) SA 667 (A)

Sibex Engineering Services (Pty) Lid v Van Wyk and Another 1991 (2) SA 482 (T)

Tjollo Ateljees $v$ Small 1949 1 SA 856 (A)

Trust Bank van Afrika Bpk. v President Versekermgsmaatskappy Bpk. en 'n Ander 1988 (1) SA 546 (W) op 552 E-G 
